Cuadernos de Lingüística Hispánica nº 23

ISSN 0121-053X • ISSN en línea 2346-1829

Enero-Junio 2014, pp. 151-170

\title{
English teaching through project based learning method, in rural area*
}

\author{
RUBY JACKELINE PINZÓN CASTAÑEDA** \\ rubypin27@ hotmail.com
}

Recepción: 15 de septiembre de 2013

Aprobación: 5 de noviembre de 2013

* ${ }^{-}$Este artículo es el resultado de una investigación terminada en la asignatura de Lingüística, del programa de Maestría en D ocencia de Idiomas de la Universidad Pedagógica y Tecnológica de Colombia, Uptc. Se adscribe a la Línea de Investigación "Pedagogía de las Ciencias del Lenguaje".

** Magister en D ocencia de Idiomas de la Universidad Pedagógica y Tecnológica de Colombia, Licenciada en Idiomas Español e Inglés de la Universidad Pedagógica y Tecnológica de Colombia.

Funcionaria de la Secretaría de Educación de Tunja en el Colegio de Boyacá, Colombia. 


\begin{abstract}
The lack of motivation to learn English is a common problem in rural schools. Students do not perceive this language as a necessary tool for the future. This study aims at describing and interpreting to what extent the implementation of the Project-Based Method helps to increase English skills as well as the development of certain human values in students. This study also aims at discussing whether increasing language skills can be compared to learning and the improvement of relationships between students and teachers. Two mini-projects were developed with eighth grade students at a public institution of Boyacá, but for this paper we took into account only one of them. The results reveal three conclusions: first, students remain motivated to learn English when addressing issues related to their context; second, they hold in their mind the vocabulary when they associate it with pedagogical activities in which they are actively involved; and finally, the strategy of mini-projects strengthens the relationship between student and teacher even more.
\end{abstract}

Key words: Motivation, context, factors affecting motivation, Project-based learning method.

\title{
Enseñanza del Inglés a través del método de aprendizaje basado en proyectos, en el área rural
}

\section{Resumen}

La falta de motivación hacia el aprendizaje del inglés es un problema frecuente en las escuelas rurales. Los estudiantes no perciben esta lengua como una herramienta necesaria para desempeñarse en el futuro. Este estudio busca describir e interpretar en qué medida la implementación del Método Basado en Proyectos contribuye a incrementar las habilidades del inglés, así como el desarrollo de algunos valores humanos de los estudiantes. Este estudio también pretende discutir si el incremento de las habilidades lingüísticas es comparable con el aprendizaje y el mejoramiento de las relaciones entre estudiantes y profesores. D os miniproyectos fueron desarrollados con estudiantes de $\mathrm{G}$ rado octavo, en una institución pública de Boyacá; pero para este documento tomamos solo uno de ellos. Los resultados revelan tres conclusiones: primero, los estudiantes se mantienen motivados por el aprendizaje del inglés cuando abordan temas relacionados con su contexto; segundo, retienen en su mente el vocabulario cuando lo asocian con actividades pedagógicas en las que participan activamente; y por último, la estrategia de miniproyectos estrecha aún más las relaciones entre estudiante y profesor.

Palabras clave: motivación, contexto, factores que afectan la motivación, método aprendizaje basado en proyectos. 


\section{Enseignement del'anglaisà travers la méthode d'apprentissge basée sur des projets, dans le milieu rural}

\section{Résumé}

Le manque de motivation vis-à-vis de l'apprentissage de l'anglais est un problème fréquent dans les écoles rurales. Les élèves ne perçoivent pas cette langue-là comme étant un outil nécessaire pour leur développement future. Cet article cherche à décrire et interpréter dans quelle mesure l'implémentation de la Méthode Basée sur des Projets, contribue à augmenter les habiletés de l'anglais, ainsi que le développement de quelques valeurs humaines des élèves. Cette étude a aussi la prétention de discuter si l'on peut comparer l'augmentation de ces habilités linguistiques avec deux aspects : l'apprentissage et l'amélioration des rapports entre les élèves et les professeurs. D eux mini-projets ont été développés avec des élèves de la quatrième, dans une institution publique de Boyacá; pour ce document-ci, on en a pris seulement un. Les résultats nous révèlent trois conclusions: premièrement, les élèves se maintiennent motivés par l'apprentissage de l'anglais quand on aborde de sujets liés à leur contexte; deuxièmement, ils retiennent le vocabulaire quand ils arrivent à l'associer aux activités pédagogiques dans lesquelles ils participent activement; et finalement, la stratégie de mini-projets renforce encore plus les rapports entre l'élève et le professeur.

Mots clés: Motivation, Contexte, Facteurs qui affectent la motivation, Méthode d' Apprentissage Basée sur Projets.

\section{Ensino de inglês a traves do método de aprendizagem por projetos, na área rural}

\section{Resumo}

A falta de motivação na aprendizagem do inglês é um problema frequente nas escolas rurais. Os alunos não percebem dita língua como instrumento necessário para desempenhar-se no futuro. $\mathrm{O}$ estudo busca descrever e interpretar em que medida 0 trabalho com o método baseado em projetos contribui a incrementar as habilidades do inglês, assim, como o desenvolvimento de alguns valores humanos dos alunos. Alem disso, a pesquisa também pretende discutir se o incremento das habilidades linguísticas é comparável com a aprendizagem e o melhoramento das relações entre alguns alunos e professores. D ois projetos foram desenvolvidos com alunos de oitava serie de ensino fundamental da rede publica do estado de Boyacá (Colômbia); mas neste documento apresentamos só um deles. Os resultados revelam três conclusões. Primeira, os alunos mantém a motivação pela aprendizagem do inglês quando abordam temas relativos com seu contexto; segunda, guardam o vocabulário na sua mente quando associado com atividades pedagógicas nas que participam ativamente; e no final, a estratégia de miniprojetos estreita ainda mais as relações entre aluno e professor.

Palavras chave: Motivação, contexto, fatores que afetam a motivação, método, aprendizagem baseado em projetos. 


\section{Introduction}

Motivation is an essential factor in English language learning. The more motivated students are, the better their English learning is.This small scale project was aimed at determining to what extent the PBL Method keeps the students motivated to learn the foreign language. It was evidenced through the improvement of the language skills. The participants are twenty three eighth graders from a rural public school from a town, in Boyacá. Motivation to learn English positively influences the willingness to work in class. It is comparable to the quality of English learning.

The way in which the focus of the research was selected stems from a questionnaire previously applied to the students. This questionnaire was aimed at determining how motivated the students were to English learning. Also, informal talks on how the students have experienced English learning process in past years were registered in the field notes. The analysis of these instruments determined the high lack of motivation to English learning. The main reason of this lack of motivation stems from past negative experiences. These negative experiences had to do with the form as they were corrected their mistakes and the teaching method focused mainly on grammar. These instruments previously applied to the students allowed the research to address the research problem.

This study is divided into three parts. The first part explains the statement of the problem, the contextual, theoretical and methodological conditions leading to the development of this research. The second part summarizes the procedure to conduct the research. The third part, describes the findings and conclusions.

In the next part, I will explain the statement of the problem based on the instruments mentioned above. 


\section{Thestudy}

\subsection{Statement of the Problem}

Eight graders exhibit a high lack of motivation during English classes. For a long time, some students were asking permission to go home. These absences were especially notorious in the English class according to the assistance register. The students who attended classes were asked about this situation. Most of them mentioned their nuisance with English classes. These informal conversations were systematized through a questionnaire aimed at find out common causes of this demotivation.

First, Most of them revealed negative experiences in the past. These experiences related to the inappropriate form how they were corrected their mistakes, especially in the oral activities. They mentioned humiliating comments by the teacher and sometimes she looked angry. As López, Encabo, Iseni and Clarkson (2007) mention how the self-credibility gets lost when the learners are given negative, offensive comments about their performance.

Second, students perceive English class as a boring activity. They explained this negative perception because the classes were focused on both grammar and translation. Most of the time, the students were asked to translate texts. Mostly, the teacher focused her explanations on grammar teaching and they perceived these classes as monotonous activities. Ahmed (2013:19) states how students feel unmotivated when the English teaching strategy is focused on "lecturers dealing with grammar"

Third, the students perceive English as other subject matter of the curriculum. They feel English learning is only a requirement to advance to the next grade. $\mathrm{O}$ the other hand, some students state that they do not need English because they do not have expectations of traveling or working abroad where English is needed. The students view English-speaking countries as an "impossible goal". They view economic factors and the language as their main difficulties to travel abroad. They relate this situation with the lack of opportunities.

This high lack of motivation to learn English has not allowed the students increase their language skills. It has demotivated the teacher as well. So, the research is aimed at improving the language skills through a pedagogical strategy which increases both their motivation and English skills. It is because a motivated 
student will always be interested to improve his listening, reading, writing and speaking skills

\subsection{R esearch questions}

\subsubsection{Main question}

To what extent does Project Based Learning Method keep the students motivated to learn English?

\subsection{2 sub-question}

What language skills and virtues of eighth graders does PBL Method enhance?

In the next section, I will explain the theory review which supports this research.

\section{Theoretical framework}

The present theory review exposes the main constructs upholding this paper. First, some definitions of motivation by different authors are included. Second, I analyze some factors affecting the EFL learning process, especially in rural contexts. Third, I explain some considerations to bear in mind. Finally, Project Based Learning Method is explained.

\subsection{Motivation}

Gardner (cited by Root, 1999) associated motivation with both a high effort and desire to learn the target language. This concept is focused on inner reasons, which are only perceived when positive attitudes of the learners appear during the learning process. In other words, motivation entails feelings as involvement, effort, persistence and enjoyment during the learning process.

English learning motivation, as Peacock (1997) states, consists of a high degree of persistence in achieving the learning task. This persistence continuously will be evidenced by attention. Besides, the learner will always show an active role during the learning process. A motivated learner frequently looks enthusiastic and participative

Based on my experience, motivating students of the rural context to learn English is not an easy task. Most of them perceive English learning as a goal disconnected from their lives. They perceive English merely as a subject matter of the curriculum. The reason by which they perceive English as detached of 
their interests underlies their "future goals" that circumscribe to finish their secondary school and getting any job. For instance, males expect to become cane growers and females want to travel to the downtown to get any job.

D ornyei (1998) introduced some relevant theories about motivation. He mentions Ajzen's theory or theory of planned behavior. This theory is supported by the principle of "perceived easy or difficult of performing the behavior" $p$. 119; In other words, the individual's perception over his ability to achieve a goal will determine the grade of his behavioral control. Based on my teaching experience, most of students exhibit a negative self-perception over achieving their goals. It was evidenced during the informal conversations with the students.

In sum, the students are required to modify their beliefs about both English learning and their future goals. Students are also required to feel English learning as a need to satisfy their future goals. It will avoid the students perceive English as an additional subject matter from the curriculum. This change implies the students to improve their project life. Perhaps, raising the future goals of the students make them think of English as a necessary tool to ensure their success.

English teachers focused on magnifying students' project life should reflect about some factors affecting their motivation in order to foresee some difficulties during this purpose.

\subsubsection{Factors that cause high lack of motivation to learn English as foreign language, in rural contexts}

Some factors that affect the performance during English learning process have been identified in different settings. These factors are included in this research since they are common ones in settings where English is taught as a foreign language.

Keblawi (1998) mentions attribution theory of the student. It comes when the students relate their achievements or failures with past experiences. So, these past experiences may have internal of external causes. When internal causes (lack of knowledge e.g.) are self-attributed by the individual, then it is probably the motivation to decrease. It is because he has not control over it. Whether the learner determines his failure to laziness or neglect, then he feels he can change. In doing so, his attitude and his motivation may increase.

External reasons appear when the individual perceive external factors as the cause of his failure. These external causes may provoke a high lack of 
motivation. It is because the individual feels he does not have control over them. According to my experience, two highly influential external factors have decreased the English learning motivation. These factors are students' negative experiences in the past about teachers correcting mistakes and teaching strategies only focused on grammar. It might explain their high degree of lack of motivation to English learning. This analysis lights the way to decide about adopting teaching strategies to keep the students motivated.

Souriyavongsa, Rany, Zainol and Mei (2013) identified some factors affecting the English learning as a foreign language. The main difficulties they identified are: a) the lack of exposure to the language outside the classroom, b) the students exhibit a high shortage of vocabulary limiting their performance, c) the lack of motivation or the negative attitude to learn English when learners do not see the need to use it.

According to the data, the lack of motivation of the students stems from external factors. They mentioned some negative experiences in the past, when teachers corrected their mistakes. It provoked them to feel ashamed. They were taught English by a Spanish teacher with no appropriate preparation for English teaching. Moreover, her classes were focused on grammar teaching. The other reason of this lack of motivation is the negative perception they have because they feel English disconnected of their lives. Based on this review, a question comes to address the methodology: what is the learning strategy that allows students perceive English as a necessity and an enjoyment?

In the next paragraphs, some considerations to bear in mind about how to enhance motivation will be addressed.

\subsection{Some considerations to bear in mind to enhance learning motivation}

The motivation will be perceived when the students know how to selfregulate their attitudes, it is, they focus their action on their learning when they experience a positive self-perception about their progress. Some relevant aspects are mentioned to make the motivation possible during English learning process.

The teacher role is an influential factor in increasing motivation. Hardré, Sullivan and Roberts (2008) define the supportive teachers as those who consider the prior knowledge of the students; they also assess the work based on the students effort and take mistakes of the students as learning opportunities p. 20. 
Some common learning strategies to rural contexts may be applicable in order to enhance learning' motivation. Hardré et al (2008) mention some strategies to enhance motivation: supporting learning and future goals, to make the content relevant, student valuing and perceived competence p. 24. Concerning to make the content relevant, it refers to the ability of the teacher to make useful the content of the subject and link it to their everyday lives, it is "to put content in context".

From my experience, these four motivating strategies should be connected. They appear chained to one another. When the content is based on the students' preferences they show more attentive and valued. Additionally, the teacher can lead to many opportunities for improvement as possible.

Students from rural context show very noble and they consider the teacher as the highest authority at the school. The teacher can take advantage of this credibility by the student in order for the students to lead their efforts to improve their quality of life.

In sum, English teacher must promote settings where English teaching enhances both communicative competence and the opportunity for the student view a best lifestyle.

In the following section, the concept and phases of Project Based Learning Method will be addressed

\subsection{Project Based Learning}

Project A pproach is an instructional model which includes a problem and finishes with an authentic product. The role of the student is defined as an active problem solver. Also, the student may become a researcher and participate in making decisions.

The problem, as a starting point, helps the students to construct their knowledge about any discipline. The students engage in solving a problem while they use the language as a necessary tool. So, it creates the necessity to use the language during the whole process. In other words, when the students get involved in real-world activities the language learning gains a high significance.

\subsubsection{Phases of the Project Based Learning}

Katz and Chard (1989) have proposed and re-defined the Project Based Learning with the following three stages. This method aims to activate and enhance 
students' motivation and to exercise intellectual and virtues, such as the creativity and the cooperative work using the four skills. PBL Method involves three stages as follows:

\subsubsection{G etting started}

The aim of this step is to select and refine the topic to be studied. The teacher and students make a list of familiar topics as well as authentic and personal experiences that are memorable to them. Also, they make connections between what they had read or heard in other areas and in their daily lives. Topics to be explored are discussed in detail. Usually, students elaborate questions to be analyzed. These questions contribute to focus the topic and predict the findings at the end of the project. In this case, the students were focused on thinking and solving a school problem.

\subsubsection{Field work}

This is the project itself. Learners can investigate about events, objects, places or topics. It allows them to get in contact with different contexts and activities. In addition to increasing English learning motivation, through their work, students can draw skills from observations, construct models, and verify their new understanding. This process of understanding of the content was possible when the student collected information about the history, description and nutritional facts of the fruits.

\subsubsection{C ulminating and debriefing events}

In the last phase, students demonstrate their acquired knowledge. They prepare and present information through different artifacts and their own contributions. Previously, proposed questions by the teacher will be answered during the final stage.

The variety of final tasks in foreign language teaching is the component to prepare learners to use English in the world beyond the classroom. Here, the classroom environment becomes a rehearsal. Activities to report tasks using different materials will allow learners to experiment with the roles they use in real life.

By the end of the activities and results, students and teachers will become closer to each other, based on the principle of collective participation. This collective participation refers to the joint of peers in order to achieve the main goal, according to the task. It means that the students have forgotten their disagreements and they work together. 
Spanish and English languages are used to integrate pre-concepts to enable them to interact. The foreign language usage is promoted in all phases of the activities and classroom interaction to learn a new way to communicate ideas, feelings, emotions and knowledge (Silberman, 1996).

At the same time, students receive and comprehend messages about the complexity of their work and about their language ability during learning situations. Using communicative tasks in the classrooms is preferred. Learners require comprehending, manipulating, producing, or interacting in the target language while attention is principally focused on meaning rather than form (Nunan, 1989).

Interesting ideas, conversations and comments emerge after hours of practice because speaking is perhaps the most demanding skill for the teacher to teach (Willis, 1983). Each class is a challenge because oral fluency is a communicative weakness. Students feel insecure and limited when they try to comment on something and they do not know how to say what they really think.

In the next section, I will explain the pedagogical proposal that I applied with eighth graders. It was designed and applied taking as base the three stages of Project Based Learning Method.

\section{Pedagogical proposal}

In this part of the paper, I explain how the students and I developed a project. This explanation includes the instructional question, the teacher' objective, the students' objective and a brief summary of the procedure to implement the steps of PBL Method. I developed two projects with the students: Let's build a Kiosk and The Wonderful World of the Fruits. I only will refer to the latter project. The workshop was aimed at providing the students with opportunities to practice the four skills. Based on this idea, the next instructional question and objectives were proposed:

\subsection{Instructional Q uestion}

How can students improve their English skills by solving a school problem?

\subsection{Teacher 0 bjective}

To propitiate activities for promoting social virtues and English skills by applying Project- Based Learning Method.

\subsection{Student 0 bjectives}

To discuss about school problems that affect the students. 
To read relevant information about themain topic addressed to solve the problem.

To socialize the information in order to promote the solution to the problem.

To promote peers' positive attitudes to solve school problems.

\subsection{D evelopment of the project: TheW onderful World of theF ruits}

The project: The Wonderful World of the Fruits was planned based on Project Based Learning taking into account the three steps as follows:

\subsubsection{G etting started}

The students discussed by teams about problems that were affecting them. After one hour, monitors of the groups explained different problems affecting the school. The class was divided in six groups of four students. After one hour, the monitors explained the different problems. Some of them were: the lack of a nursing room, the reconstruction of the kiosk, the school transport, the waste of food by the students in the lunch time. After that, the students exposed the possible problems to be discussed. The teams were asked to decide about the main problem to be solved. They wrote about their choice and a common problem emerged as follows: Most of the students were throwing part of the lunch away, mainly the fruits. It was because they usually feed domestic animals, like the pigs, with these fruits. These fruits were the banana, the melon, the papaya and others. It is because there is abundance of these fruits. The teacher guided the students about how to solve these problems. So, the students suggested finding out information about the importance of these fruits. The teacher considered relevant that each group will find out information of a specific fruit. Additionally, a group was asked to explain how to prepare a fruit salad as an alternative to eat these fruits. Additionally, the teacher asked the whole class what suggestions they will give to their peers to use the fruits in an appropriate form.

\subsubsection{The field work}

The teacher guided the students in order to collect only relevant information about the fruits. In doing so, the students designed power point presentations with illustrations and key words to recall the information when socializing the work. This information contained a brief description of the fruits, their origin and their nutritional facts. Then, y summarized the written information in cards. The students that prepared the fruit salad designed flash cards with target vocabulary as: to wash, to clean, to peel, to chop, to mix, in order to make clear vocabulary and the process of preparing this food. 
The teacher considered appropriate to present this information with their peers before socializing it with the other grades. It would allow the students to feel confident when they spoke.

\subsubsection{Culminating and debriefing events}

The day of socializing the information with the other grades, eighth graders were very excited. This day, they wore their best clothing. Then, the work teams shared this information with ninth and tenth graders. The teams socialized the information about these fruits. They also suggested how profitable these fruits were to prepare fruit salad, juices and others.

The last team had prepared enough fruit salad for the guests to the activity. They previously had videotaped the process of preparing the fruit salad, guided by the teacher. Some of the students explained the process by using the recording and the raw material. Also, these students suggested advices about how to manipulate the fruits and they were wearing plastic gloves. After, the students designed a billboard with photos about the project.

After a long time and suggested by some teachers, eighth graders socialized this information with the smaller students of primary school in both Spanish and English languages.

The next section of this paper accounts for the research design considered to structure this research study.

\section{Research design}

This section includes the type of study, methodology, setting, population, participants, and the teacher' role and data collection process where instruments and procedures used to gather information are displayed.

Type of study and methodology

This is a qualitative research because it is focused on interpreting findings. The research will describe information about how Project Based Learning method enhances some virtues and English skills. According to Merriam (2003) the qualitative research is focused on meanings which are constructed by the interaction of individuals with the reality. Also it is a descriptive case study because it attempts to identify the language skills and virtues revealed by eighth graders when the teacher applies Project Based Learning Method. 


\subsection{Setting}

This study was carried out in Institución Educativa Jordán. This is a rural public Institution from Moniquirá, in Boyacá. All the students belong to the rural area and these students are in eighth grade of high school. They follow a Vocational High School through an agreement with SENA Institution.

\subsection{Participants}

The participants in this project are seventeen students: six female and eleven male students. They ranged from thirteen to fifteen years old. They all come from the rural area.

\subsection{D ata Collection: Instruments and procedure}

\subsubsection{Semi-structured interview}

This type of interview allows the interviewer to include questions emerged from the interviewee's answers. Ododa (2009) states how this instrument can be focused on attitudinal questions. It implies that opinions and values of the respondents can be perceived through their answers. This semi-structured interview was applied to perceive virtues and language skills that the students felt as acquired during the process of the project.

\subsubsection{G roup interview}

Aubel (1994) defines this instrument as an unstructured conversation. The dialogue begins when the monitor asks a guide question to the participants in order to give them the opportunity to exchange ideas. In this case, the guide question was aimed at finding out how they felt during the whole process of the project. Additionally, they were asked to reflect about what differences they found between the method used by the last teacher and the current one.

\subsubsection{Artifacts}

The artifacts consisted of materials produced by the students during the teaching learning process. Goetz and LeCompte (1984) define artifacts as products that learners make and do. In this case, the artifacts consisted of the summaries, the flashcards and the power point presentations designed by the students. This analysis was aimed at detecting the progress in the four skills.

In the next section, I will explain the data analysis process and the findings to solve the research question. 


\section{5. $D$ ata Analysis}

Through the analysis of the information, common patterns emerged. I used triangulation to validate. Triangulation, as Guion (2002) explains, consists

of a method to validate the findings of a qualitative research. Methodological triangulation as Guion (2002) claims consists of using different qualitative or qualitative methods to validate the information. Surveys, interviews or other methods can be used to validate the findings. When these methods offer the same conclusions, the research has been validated. In this case, I mention methodological triangulation due to I used three data collection instruments mentioned above.

The project mentioned in this article was called: The Wonderful World of the Fruits. This project was developed in a period of six weeks. During this time, the students were guided by the teacher during the three main stages of PBL Method. The semi-structured interview was applied to the students at the end of the three stages. This process allowed me to verify both the advances in the language skills and interaction. The group interview was applied when the project finished with the purpose to collect general opinions of the whole process. The artifacts were analyzed when they emerged. The conclusions were written in my notebook.

D uring the process of collecting data, I used grounded approach. Freeman (1998) suggests four steps: naming, grouping, identifying relationships and displaying. After this, I identified common patterns and I connected the information with the research question.

\subsection{Findings}

The names of these categories emerged from repetitive statements and commentaries done by the students in the different instruments. So, two categories emerged:

\subsubsection{Turning my memories into words}

Most of the student coincided in stating how the activities done during the whole process made them easier to speak in the different stages of the project.

"Cuandb yo estaba haldandb de cómo preparar la ensalada de fintas me acordé de arandbla preparamos Fuecamo si una pdíaula pasara por mi cabza" (Juan)

In this case, Juan is confirming how a highly motivated student feels 
involved and enthusiastic during the English learning process. He mentions how easy it was to explain the process of preparing the fruit salad because of his contact with the raw material.

"Hablar fue más fáil parque me accrdé de los dibujos que hioimos en las fichas" (Ridhard).

"Meaccoédela informadón en Inteme y pudehadar un poro mgior" (Luisa).

The students evidenced how speaking was easier when they remembered the activities done during the whole process.

In the same line, the students stated how motivated they felt when they were talking to the smaller students because they felt they were important people.

"Comoya habáamos habladb da tema, fuemás fáal arandb hablamos frentea los de primaria" (Ridhard).

Richard mentions how motivated he felt when talked to his younger partners. His self-esteem has increased.

“Comtí algunos errores pero nadie se dio de cuenta” (Richard)

Richard is stating how his self-confidence allowed him to take mistakes as normal in his learning process.

Even though the students made mistakes, they evidenced how confident they felt when they talked to the other students.

\subsubsection{Let's work together}

This category evidences how PBL Method enhances some virtues of the students. These virtues are inner and social ones. Students' answers inspired the name of this category. Some examples are as follow:

\section{“Venga yolepregunto y después usted mepregunta a m'(Larena)}

Lorena is showing a high feeling of solidarity. She thinks not only of herself but also she looks concerned about the progress of her partner.

"Aprendmosapedkrlatimidz arandbinteractuamosconnuestroscompañeos" (Terea).

English learning process through PBL Method allows the teacher to go beyond the life of the students. Most of the students feel confident when talking to their peers. 
These students reflect about the importance of the cooperative work to improve their learning. The collaboration is an important virtue to improve both the English learning and the coexistence.

The self-confidence of the students was also improved. Some students evidenced this:

“Mesentí bien parquequeía pasar al frente" (Fermandb).

“Me equivoquéy nadeseburón” (Gima)

Gina's words state how the respect between students has increased. The respect to the opinion is a requirement to ensure the learning improvement.

Some students reflected about social importance of the activity:

"Megustó \& trabajo parqueaprendimos ingés y hacer algo útil” (Ridhard)

"podemos enseñar a ctros cosas impatantes, en ingles" ( Larena)

Richard and Lorena highlight the importance of sharing the knowledge with other people.

The students evidence a positive attitude to the English learning. They take the English learning not only in terms of language itself but also as a source to share knowledge.

The teacher-student relationship was also improved taking into account that these students from rural context look very shy to interact with the teacher:

"Profe ¿cómo sepronumia eto?" (Leenardb)

"Profe, setoma una foto con nostras" (Jessika and Laura)

Jessika and Laura evidence how important this activity has been for them. They have included the teacher as an important person during this process.

"Profe, cómo queda mijor d carte: así o as'" ( Sergo)"

The students of this rural context felt more confident with the teacher. It was possible because they shared activities where they exchanged ideas to develop the project.

This confidence showed by the students made the teacher feel satisfied. This time, the teacher role was taken not only as a guide of the students but also as a real helper to foster the English learning. 
English teaching through project based learning method, in rural area

\section{Conclusions and implications}

Project Based Learning contributes to enhance not only the motivation of the students to learn English but it promotes individual and social values to improve the coexistence. When English learning is based on solving a problem the learning and teaching English process becomes more motivating. It is because the students feel seriously engaged in solving the problem. They enjoy the activity and all of them cooperatively work.

Inner and social virtues are enhanced through the application of PBL Method. The self-confidence, the cooperation, the tolerance are some values that the students felt they learned in this activity.

Speaking was the language skill more promoted during the process. The students felt confident when they spoke about the different target topics during the different presentations. Also, they learned to interact in their native language when they exchange ideas during the team work and the different activities.

The English teacher is a propitiator of activities which promotes the cooperative work and activities where English may be perceived as a need. The connection between English learning and the context of the students make possible that the students perceive English as a need. In doing so, English teacher becomes a leader promoting social activities to improve the quality of life of the students.

English teaching and learning process implies to go beyond the classroom. Teacher and student can get involved in the social life of their context. The student- centered class implies that he can participate in making decisions about the way of solving the problem, the content and the process to develop the project. The teacher is a guide and a propitiator of spaces where the students have the opportunity to increase their individual and social values and it will allow them to increase their language skills.

\section{R eferences}

Ahmed, S. (2013). The Current Practices of Teaching Grammar in CLT at Secondary School Level in Bangladesh: Problems and Probable Solutions. In Theory and Practice in Language Studies, Vol. 3, No 8, (1328-1334) 
Aubel, J. (1994) G uidelines for Studies Using the G roup Interview technique International Labour O ffice G eneva World Employment Programme. International Labour Ornanization.

D ornyei, Z . (1998) Motivation in Second Foreign Language. Language Teaching Volume 31 (117-135) Thames Valley University, London.

G oetz, J. P. and LeCompte, M. D. (1984). Ethnography and QualitativeDesignin Educational Reserch Orlando, FL: Academic Press.

Guion, L. ( 2002) Ttiangulation: Establishing the validity of Q ualitative Studies. Institute of Food and Agricultural Sciences. University of Florida.

Hardré, P. Sullivan, D. and Roberts. N. (2008) Rural Teachers' Best Motivating Strategies: A Blending of Teachers' and Students' Perspectives. (19-31).

Katz, L. G., \& Chard, S. C. (1989). Engaging Children's Minds The Prgeet Approach. Norwood, NJ: Ablex. (ERIC D ocument No. ED 407074) February 2012.

Keblawi, F. (1998). A Review of Language Learning Motivation Theories (23-58).

Lopez, A. Encabo, E . Arburim, C. Paul (2008). Teachers' Attitudes Towards Correcting Students' written errors and Mistakes. En Porta Linguarum. Vol. 10, Juny. (2130).

Merriam, S. (2003). Case Study Research in Education: A qualitative Approach. San Francisco. Oxford: Jossey-Bass Publishers.

Nunan, D. (1989). Designing Tasks for the Communicative Classroom. Cambridge: Cambridge University Press.

Ododa, H. (2009). Posted on March 2010 Political science.

Peacok, M. (1997). The Effect of Authentic Materials on the Motivation of EFL. ELT Journal Vol 51 Oxford University Press.

Root, E. (1999). Motivation and Learning Strategies in a Foreign Language Setting: A look at a Learner of Korean. ( CarlaWorking paper \# 14) Minneapolis. University of Minessota. Center for Advanced Research on Language Adquisition. Retrieved from http:// www.carla.umn.edu/ resources/ working papers/

Silberman, M. (1996). Adive Lerning 101 Strateejes to Teach Any Subet. Boston: Allyn and Bacon. 
English teaching through project based learning method, in rural area

Souriyavongsa. T, Rany. S. Zainol.M, Lai.L. (2012). Factors Causes Students low English Language Learning: A Case Study in the National University of Laos. International Journal of English Language Education. Vol 1 No. 1.

Willis, D. (1983). The Implications of Discourse Analysis for the Teaching of Oral Communications.Birmingham University. 